\title{
SUÇSUZLUK KARİNESİ: KAVRAM HAKKINDA GENEL BILGILER VE AVRUPA İNSAN HAKLARI SÖZLEŞMESİ
}

\author{
Dr. Metin FEYZIOĞL $L U^{\text {k }}$
}

\section{GİRIS}

Adma kimi zaman masumluk karinesi, ama daha doğru ve Anayasaya uygun bir ifadeyle, suçsuzluk karinesi denilen bu kavram. Kıta Avrupasına, 26 Ağustos 1789 tarihli Fransız Kişi ve Vatandaş Hakları Bildirgesi ile hukuken ayak basmış ve o tarihten sonra Fransız İhtilalinin rüzgarlarıyla tüm Kıtaya yayılmıştı'.

Bildirge incelendiğinde, suçsuzluk karinesinin hükme bağlandığı veya esas alındığı 7., 8. ve 9. maddelerinde, diğer haklarda olduğu iizere, tabii hak görüşünün temel alındığı görülür ${ }^{2}$. Geçen yiizylllarda Tabii Hukuk Okulu etkinliğini ve kabul görürlüiğünư büyük ölçüde yitirmiş olsa bile, suçsuzluk karinesi zaman içerisinde bütün medeni devletlerin ortak değeri haline gelerek: insan

Ankara Üniversitesi Hukuk Fakültesi Cezal ve Ceza Usulü Hukuku Anabilimalalı Y.ırlume Doçenti

1. Franss\% thtilalinden önce yazdığ eserinde Beccaria "Bir adama hâkimin hühimünden

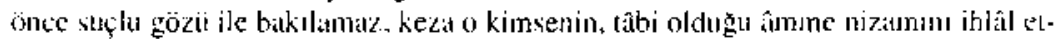

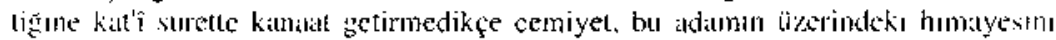
kildırmaz" demek suretiyle. suçsuzluk karinesinin önemini vurgulamıșur (Becciria. s.. 157-158)

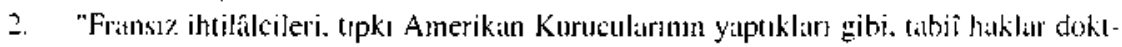

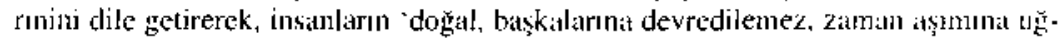

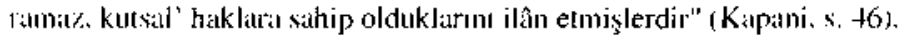

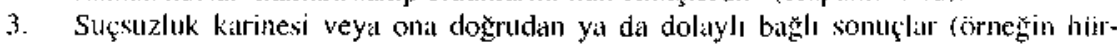
riycti mahkumiyes kararmanda önce, idare tarafindan kısıtlanan kişilerin cn kısil sil. 
haklan ile ilgili temel milletlerarası metinlete girmiştir'. Buguin artık, suçsuzluk karinesinin muhakeme hukukunun ve diirtisı muhakeme hakkının temel bir uaşı olduğuna kuş̧u yoktur’.

Aşiặ̆da suçsuzluk karinesini açıklarken önce. kav'aımın poritil hukukumuzdaki temellerini ele alacak, terim sorunu iizerinde duracik, anlimını, kapsamın ve toplumsal etkililiğini inceleyeceği Daha sonfia suçsuzluk karinesini. AlHS md. $6 / 2$ çerçevesinde. Sï\%leşme denetim organlarının oluşturduğu içtihatlarla birlikte. ayrnntılı olatrak sunmaya çalışacağı.

\section{SUÇSUZLUK KARÍNESİ HAKKINDA GENEL BILGILER: POZITIF HUKUKTAKİ TEMELLERI VE TERIM SORUNU, ANLAMI VE KAPSAMI, TOPLUMSAL ETKİLILİĞİ}

\section{POZİTIIF HUKUKTAKİ TEMELLERI}

Suçsuzluk karinesi, Anayasamizın 38/4. maddesincle bir lemel hak olarak dǜenlenmiştir. Buna göre, "Suç\}uluğgu hükmen sabit duncaya kadlar, kimse suçlu sayılamaz." Suçsuzluk kartinesinin. Anayassinn "lemel hak ve hürriyetlerin kullamlmasinin durdurulması" kenar başlıklı 15/4. maddesinde. savaş, seferberlik, sikyyönetim ve olağanüstii hallerde dahi dokunulması mümkün olmayan çekirdek haklar kategorisinde yer aldığı da belirtilmelidir.

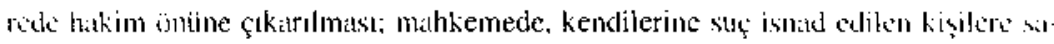

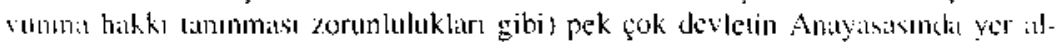
matkiadil. Örnck olinak bkz. 1996 tarihinde kabul olunam Ukraynis Anayiailss mu.

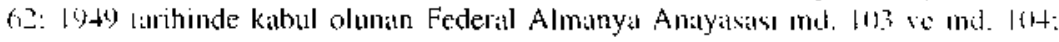
Mikir Cumburtycli Anayasisist mci. 57/2

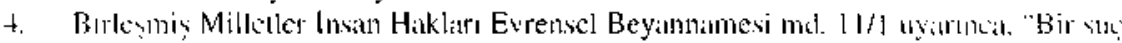

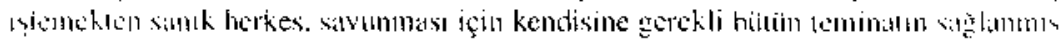

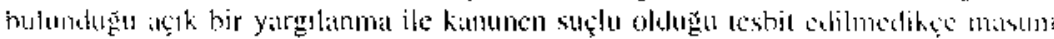

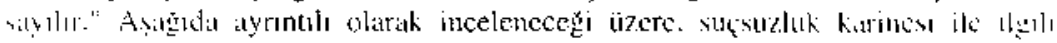
dy

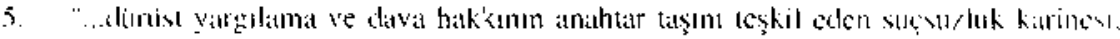
hiı̈ün tısul isteminde temeldir" (Dönmezer, Tusaurı, s. 25). 
Temel bir hak olan suçsuzluk karinesi, sadece Anayasa değiI. Türkiye tarafindan onaylanarak bir iç hukuk normu haline gelmiş olan AIHS md. 6/2 tarafından da güvence altına alınmıştır. Sözui geçen madde hükmü, aşağıda, AIHM ve AIHK kararları da ele alınarak ayrintılı olarak incelenecektir.

\section{TERİM SORUNU}

\section{A. Suçsuzluk Karinesi mi Masumluk Karinesi mi?}

Kavrama verilen karine nitelendirmesiyle ilgili görüşlerimiz. saklı kalmak kaydıyla, öncelikle "suçsuzluk karinesi" ile "masumluk karinesi" terimlerinden hangisinin kullanılması gerektiğini incelemek istiyoruz.

Anayasamı, 38/4. maddesinde, "masumluk"tan değil, "suçsuzluk"tan bahsetmektedir . Buna karşın gerek BM Insan Hakları Evrensel Beyannamesinde (md. 11/1) gerekse AIHS'nde (md. 6/2) "suçsuzluk" yerine, "masumluk" nitelemesinin kullanıldığın belirtmeliyiz.

$\mathrm{Biz,}$ makalenin başlı̆̆ından da anlaşılacağı üzere, "suçsuzlık karinesi" terimini kullanmayı tercih ediyoruz ${ }^{7}$. Bunun nedeni. ceza muhakemesinde kişinin sanık sıfatını almasıyla birlikte ${ }^{x}$, sanıklık

6. Matar Cumhuriyeti Anayasasmm 57/2. maddesinde de hiç kimsenin mahkeme tał. rat indan hukuken geçerli bir karar verilmediğ süirece "suçla salyılamayalcağı" häikme bigliglinm!stir.

7. Krs. Yuice, $\mathrm{s} 32$.

8. Kişiıin sanıklık sılatı, suç isnadı ile başlar. Suç isnadamm davat açılması ile veyaı

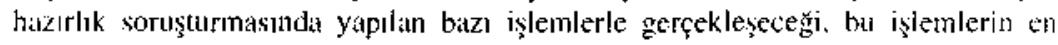

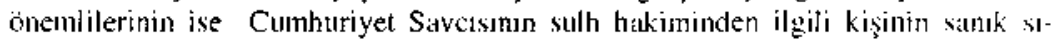
fatıyla sorguya çekilmesini ya da tutuklanmasm talep etmesi olduğu ileri siirülmiiştir (Kunter, ss. 439-440). Simıklık stfatımm. ilgilj kişinin isnald $0 \mathrm{~g}$. renmesinden itibaren baş̧ayacăğı, buna "geniş inlamda sanıklık" denilmesi gerektiğ̣ (Kunter/Yenjsey, ss. 398-399; Yenisey, ss. I18-119) veya yargt orgammn mïdallaalesi yoluyla yapılan ișlemlerin sanıkık stfatmi başlatacağ da düşünülebilir (Donay, ss. 27-28). Baş̧a bir görișe göre jse kovușturma organını bireye katşi fiilen veya hukuken yöneltţ̧ herhangi bir jşlem ile sorușturma bașlar ve böylelikle

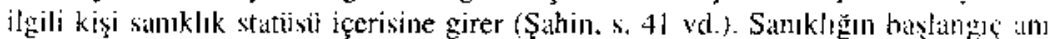
jle ilğili göriiș̣ler, objektif, subjektif ve karma teoriler olarak smiflandırılmaktadır. 
slatüsüne girmeyenlere uygulanamayan bazı koruma tedbirterinin belirli şartlar altında kendisine uygulanabilir olmasidır. Gerçekten. eğer kavamm adına masumluk karinesi denilecek olursa, orellikle. kişi hïrriyetini mahkumiyet kararundan önce ăğr şekilde sinırlayan tutuklama koruma tedbirinin masum kabul edilen bir kişiye uyguliınmatsı açıklanamà olacaktır".

Tutukiamanın bir ceza olmadığı, geçici nitelikte ve muhakemo hukuku amaçlanyla uygulanan bir koruma tedbiri olduğ doĝ̣rudur. Fakal tutuklama koruma tedbirinin tygulanmasmun birinci şatt. CMUK mu. 104/1'e göre, kişinin suçluluğu hakkunda kurveti şïphe bulummasudır". Öyleyse bu kişi, masum kabul edilen bir kiși değildir. Yalnı suçlı da kabul edilmemekıedir. Hukuki durumu. suçlu i le masum arasındaki çjøgidedir". Ancak, suçlu kabul ediłmeyen tutuklunun tabi olacağ şartlar elbette, mahkumlarm şatlarınclan çok claha larkh olmalıdır't".

\section{B. Suçsuzluk Karinesinin Bir Karine Olup Olmadığı Sorunu}

Gerçeğe uygun kabul edilen bir olaydan veya olaylal buitününden yola çıkılarak, diğger bir olayın varlığına dair karar ver-

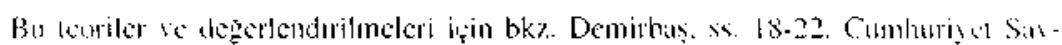

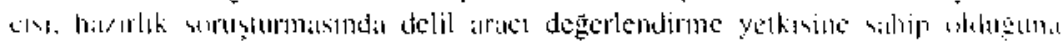

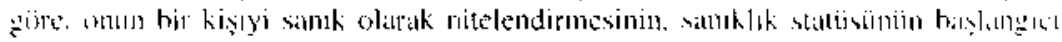

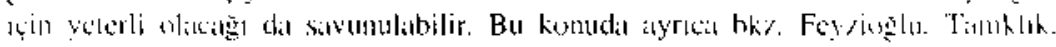
ㄴ. 45.47 .

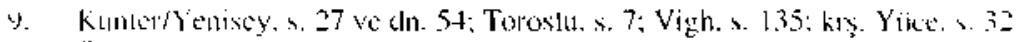

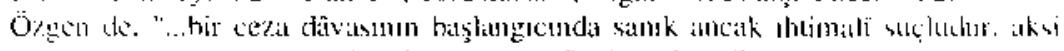

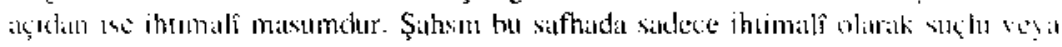

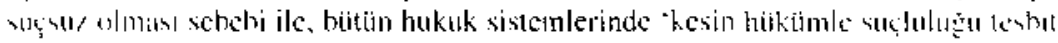

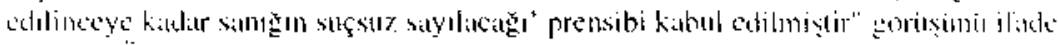

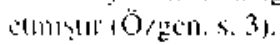

11. Centci. Tutuklamit. ss. 38-40).

II. Williallhs, s. 183: Vigh, s. 135.

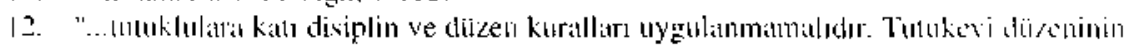

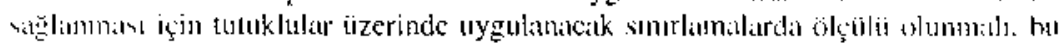

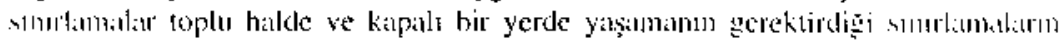

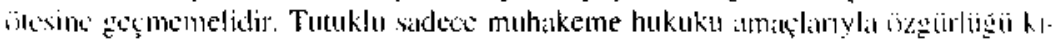

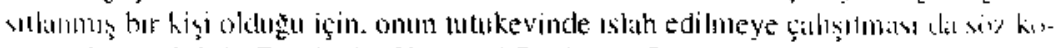

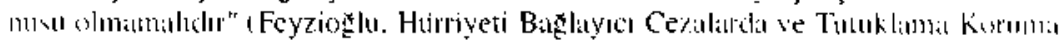
Tialhitinde. 5712 \}. 
meyi gerektiren bir kurala dayantlarak yapılan işleme, karine denilir. Hukuki olsun, fiili olsun karine, vicdani kanaate ulaşmakta kullantlan veya bir başka deyişle, ispat faaliyeti sırasında başvurulan bir işlemdir ${ }^{13}$.

Suçsuzluk karinesinde ise, böyle gerçeğe uygun ya da sabit olduğu kabul edilen bir olaydan, başka bir olayın varlığı sonucuna gidilmesi söz konusu değildir. Suçsuzluk karinesi, kişinin suçsuz olduğunun varsayılmasından ibaret bir temel haktır.

Esasen suçsuzluk karinesi yerine, "suçsuzluk varsayımı" denilmesi belki daha doğru olacaktırit. Ancak artık yerleşmiş bir terimi değiştimeye çalışmakta bir fayda görmediğimizden. karine nitelendirmesini, aslinda bir karine degil, bir temel hak anlamında olmak kaydıyla, kullanmaya devam edeceğiz.

\section{SUÇSUZLUK KARİNESINİN ANLAMI VE KAPSAMI}

Suçsuzluk karinesi uyarınca, bir kişinin suçlu olarak nitelendirilebilmesi ve hakkında ceza hukukunun alamna giren müeyyidelerin uygulanabilmesi, kesin hükümle mahkum olmasina bağlkđır. Bir kişinin mahkum edilebilmesi için ise, akla ve mantığa uygun gerekçelere dayanan her türlü şüphenin bertaraf edilmesi şarttır. Çünkü bu kişi, kanumen suçsuz kabul edilen bir kişidir. Suçlu olarak nitelendirilebilmesi, suçsuzluğuna dair bütün gerekçeli şüphelerin yenilmesine bağhlıdır ${ }^{15}$. Aksi takdirde, şüpheden sanık yararlanacaktır ${ }^{16}$.

13. Blick, ss. 1067-J1168: McCormick. s. 578 vd.: Dando, ss. 1901-19l; ityracal blis. VargadSzijer, s. 170; Cross, ss. 109.110; Taspinar, s. 533.

14. MeCormick. ss. 579-580

15. Cross, s. I119: Holten/Jones, s. 210 .

Dönmezer'c göre de suçsuzluk karinesinin umsurlarmdan biri. "in dubio pro reo" (şïphcder sanık yararlanır) ilkesidir (Dömmezer. Suçsuzluk Kärinesi, s. 68).

16. "...."suçsuzluk karinesi", suçsuzluğın tespit edilmesini de şart koşmaz.. Bu nedenle.

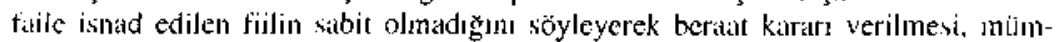

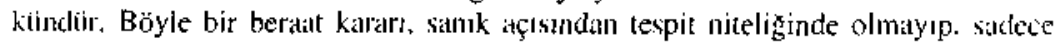
'suçsiızluk karımexinin' bir ifadexidir" (Schroeder. s. 22). 
Suçsuzluk karinesi, suçsuz kimselerin asla mahkum edilmeyeceklerini emreden bir kural değildir. Vicdani kanaale göre büküm verilmesi zorunlu olan bir muhakemede, hịç arłu edilmemekle birlikte, masumlarun da mahkum edilme tehlikesi ne yarılk ki her zaman vardır. Nitekim ispatta hedeflenen, mutlak değil. makdli gerçektir. Çünkü geçmişıeki bir olayın, buguỉn. muhakeme latiliyeti sıasinda gerçekleştitilen temsilinin, gerçeğe mullak surette uygun olup olmadığm bilebilmek mümkïn değildir ${ }^{*}$. Suçsurluk karinesinin öngürdüğ̈u husus ise. herkesin. gerçekte suçlu uha bile. kesin hükümle mahkumiyete kadar suçsu kabul edilecegidiris.

Suçsuzluk karinesinin anlamından yola çıkılarak ulaşislakak bir somuç da. suç isnadına hedef olan kişilere, kendilerini savumına hakkının verilmesi zorunluluğudur. Sanığın suçsuz kabul edilmemesi durumunda, ona savunma hakkı tanınmasina veya en a\%mdan, savunma hakkının muhakemede temel öneme sahip bir hak olarak düizenlenmesine gerek yoktur. Sanık suçsuz kabul edilliğgi içindir ki. muhakeme yapılmakıa ve maddi gerçek aranmaktatır.

Maxluli gerçeğe ulaşılmasında samığın yapmış oldığ salvunma. "ter"in karşısındaki "antitez"i oluşturmakta: sonuçta bic "sentez"e vartaralk maddi sonun çözülmektedir"." Bu itibarlá. Anay asaumm 36. maddesinde temel bir hak olarak diizenlenmiş bulunan salvunmal hakkı. suçsurluk karinesinin bir sonucu olarak değerlendirilmelidir.

AİHS die. yapmiş olduğunuz bu yorumu desteklemektedir. Suçsurtuk karinesi, aşağıda inceleneceği üzere, Sözleşmenin dürüsı

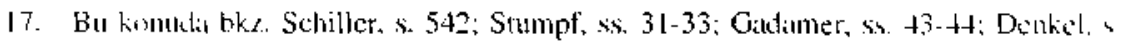
13. 23 vd: Dando, ss. 174-175: Beccaria. ss. 135-136: Frank, sh. 122-127: Golal. tein. s. 179: Dershowilz, ss. 34-37: Kunter/Yenisey. ss. 271. 547; O/getl, s. 6-14.

ik. Gomien/Hatris/Zwitk, s. 182.

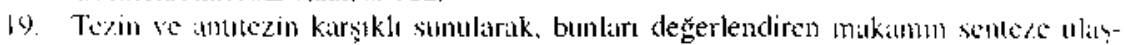
mass hakkinda bkz. Keyman, sis. I62-163. 
mubakeme hakkını" düzenleyen 6. maddesinin bir parçasıdır. Düriist muhakemenin temelinde ise santklara kendilerini savunma hakkının tanınması ve bu hakka, dürüstçe saygı duyulması vardır. Nitekim AlHM de içtihatlarında, suçsuzluk karinesi ile savunma hakkım birbiriyle ilişkilendirmektedir ${ }^{21}$.

Anayasamızın düzenlediği şekliyle suçsuzluk karinesi, sadece bir suç isnadının bulunduğu halleri kapsamamaktadır. Herhangi bir suç isnadı olmayan hallerde, resmi makamlarca kişilere suçlu muamelesi yaprlması da, suçsuzluk karinesinin ihlali olarak kabul edilmelidir.

Hemen belirtmek gerekirse, AIHS'nde suçsuzluk karinesi, sadece ceza hukuku anlamında bir suç isnadının bulunması halinde başvurulabilecek bir hak olarak düzenlenmiştir ${ }^{22}$. Bu itibarla söz konusu düzenleme, Anayasamıdaki suçsuzluk karinesinden daha dar kapsamlıdır. Ancak aşağıda görüleceği üzere, AIHS'nin denetim organları olan AtHM ve AlHK, ne zaman bir suç isnadının bulunduğu konusunda geliştirmiş olduğu içtihatlanyla, suçsuzluk karinesinin güvence altına aldığı alanı genişletmişlerdir.

20. "Diiriist muhakeme" ile kastettiğimiz, AJHS'nin lngilizce metnindekj "fiuir triatl" kirr-

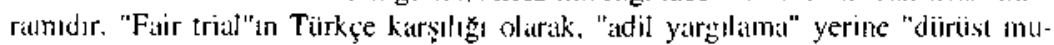
hakeme" ibatresini kullanmamızn nedeni, "dibriist" kelimesi ile "yalnus adli yollit ve hileye başvurulmaksizan ulaşlıtn adaleti": "muhakeme" kelimesi jle ise "yalme yargilamaly yapan yargoliama makammon de idil, iddia Inakammon da diirist olmasi ge-

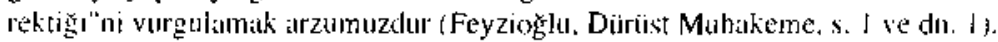

"Fiilr" kelimesini "dürüst" olitrak tercüme eden Dönmezer de şu görïsleri ilade clmiştir : "Ben "dïrîst yatggiama hakki" diyorum. Nedes, "aldil yatrglama" demiyorum? Çünkü, adil yarglama, neticesi adalelc uygun yarglami demchlit. Néticesi adalete uygun huiküm, bir takım usulsüzlijkler yapılarak dit clde edilebilit. Kişiys döver, doğruyu söyletirsiniz, buna göre de hükmï verirsiniz. Netice adjl olur. Ama diurüst yargılama olmaz. Onun için diurijst yargılaına sözcijklerini. tercih etmelidir" (Dönmezer. Tasan, s. 19).

21. Minelii judgment, 25 March 1983, series A, vol. 62, para. 15-16. 18; 34. 37, +1. Ayricit bkz. Çavuşoğlu, s. 40; Centel, Dürìst Yarglauma, s. 59.

22. BM Insaun Hakları Evrensel Beyannamesi'zin suçstuzlık karinesi ile ilgili 1 //I. maddesinin if adesi de. AlHS md. 6/2 gibi. Anayasamıla kuyasiandığnda daha dar kapsilmidir. 


\section{SUÇSUZLUK KARINESLNIN TOPLUMSAL ETKILİ İĞì}

Hukuk, toplumsal bir kültürdürr:3. Böyle olunca da. genellikle toplumsal gelişmeleri takip eder. Oysa üzülerek belirtmek gerekirš ülkemizde, sannğın suçsuz olduğunu kabul eden Anayasa hükmü ve ilgili ce\%a muhakemesi kanunlanmız, çoğu zaman toplumumu/da yayggn olarak kabul gören "sanığın suçlu olduğg" anliayış̧ndian dalha ileridjr. Ne yazık ki toplumuzda sanık, hala suçlu olatak mitelendirilmektedir-2.

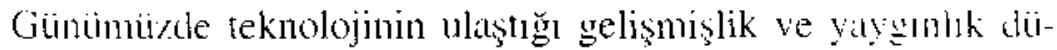
seyi. tophumbarun eskiye kuyasla çok daha kolily yönlendiritcbilmelerine neden olmaktadır. Buna bağlı olarth, tekmojiye sathip olan güçlerin, herhangi bir konuda diledikleri yoimle

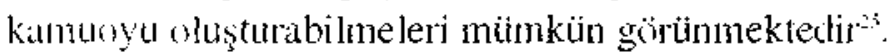

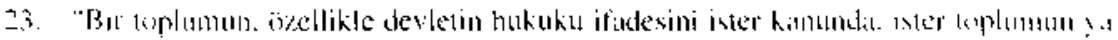

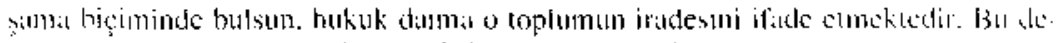
mektir ki. hukuk beseri iradedis" \{ Haffizogullan. Laiklik, s. 29)

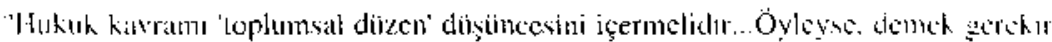

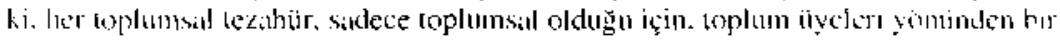
“lusulemedir" (Harfizoğultarr, Ceza Normu, s. 2l).

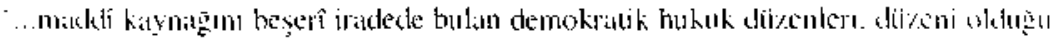

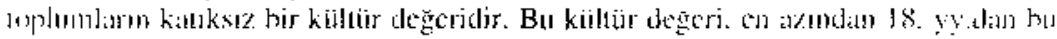

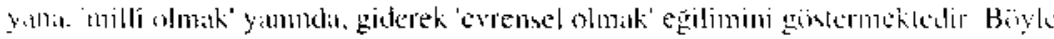

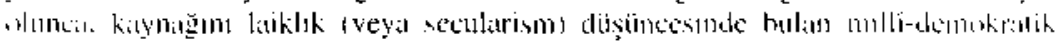

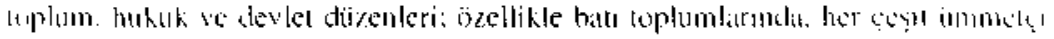

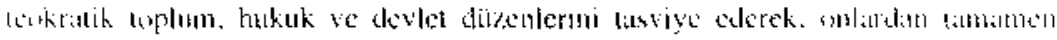

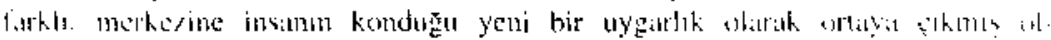

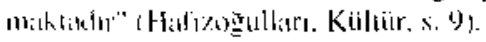

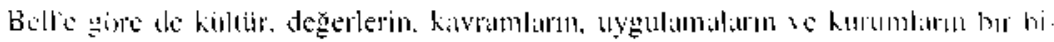

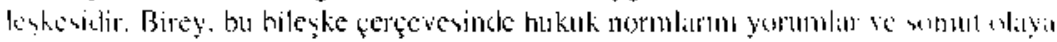
"y.utiat (Bell, s, 6+).

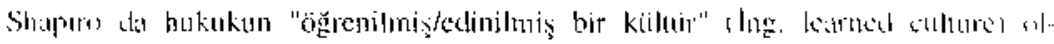
(lığ

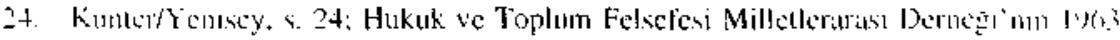

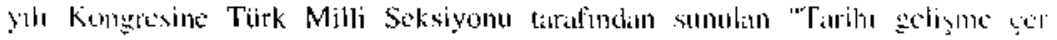

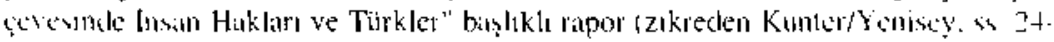
$25,112 .+48)$

2.5. Gildiuluer, $>3$. 
Toplumumuzun da, teknolojide "çă̆ atlamasına" ve "medya" denilen kitle haberleşme araçların alabildiğine kullanmaya başlamasına bağlı olarak, çeşitli yönlendirmelere açık olduğu düşüniilebilir ${ }^{2-x}$. Hatta belki de zaman zaman fazlaca etki altında kaldığı söylenebilir. Kuşku yok ki, gazete manşetlerinde, suçlularm (şiiphelilerin değil) yakalanarak veya tutuklanarak cezaevine (tutukevine değil) gönderildiği müjdelerinin rahatsızlık uyandırmaması, adliye yerine gizli kamerayla çekilmiş haber programlarına iltifat edilmesi vs., onayladığımı insan hakları metinlerindeki ve Anayasamizdaki temel haklarin toplumsal etkililiğgni sağlamakta ne kadar başarılı olabildiğimizin bir göstergesidir ${ }^{37}$.

Bu noktada, 1 Ekim 1998 tarihli Resmi Gazetede yaymlanarak yürürlüğe giren Yakalama, Gözaltına Alma ve ffade Alma Yönetmeliğinin, tutuklamadan önceki aşamada suçsuzluk karinesinin etkililiğinin sağlanmasında önemli bir adım olduğunu belirtmeliyiz. Sözü geçen Yönetmeliğin 26. maddesi uyarınca "Suçluluğu bir yargı hükmüne bağlanana kadar kişinin masumiyeti esastır ve hazrrlik soruşturması gizlidir. Bu nedenle, soruşturma safhasında gözaltındaki bir kişinin 'suçlu' olarak kamuoyuna duyurulmasına. basın önüne çıkartılmasına, yer gösterme gibi soruşturmaya ilişkin

26. Bu konada bkz. Centel, Dürüst Yarglama, ss. 58-59.

27. Böyle haberlere bir örnek: "Zorbalar cezacvinde: Lzmirde üniversitc örencisin $k$ iafirıp gimlerce tecaviiz eden iki sanık tutuklandı. Bornovida Ege Universitesi ..... ögrencisi 23 yatşndaki ... yi kaçırıp 4 gün boyunca tecaviiz eden ...... ve .... dìn nöbetçi mathkeme tarafmdan tutuklanarak cezaevine konuldu" (Hürriyct Gazetesi. 7 Arilık 1998, s. 3). Haber metnindeki isim ve kimlik belirleyici bilgiler. Laratimuzcis çlk:arilınıstur.

Schroeder. Almanya açısından basın ve stçsuzlık karinesi ilişkisini şu şekilde açıktamaktadır: "Suçsuzluk karinesinin doğurduğu di ğger bir sonuç, basin hukuku ile attitkillıdır. Kendisinden şüphelenilen bir kişi (verdachtige), basan tarafindan fail olarak nitelcndirilemez. Meşhut cürüm surasmda yakalanmış ofsal daht bu böyledir. Bu nc(lenle basinda, günṫmuizde genellikle muhtemel fail (mumassliche Täter) terimunin kullanıldığınt görmekteyiz. Ancak burada ortaya çıkin problem basının Avrupa devictlerinde prensip olarak özel teşebbüs taratindan organize edilmiş olmasa nedeni ile Avrupa Inæan Hakları Sözleşmesine dogrudan doğruya labi olmamasindinn kaynaklanınaktadır. Federal Almanya'da basın birliklerinin oluşturduğu bir otokontrol mekanizmasi vardir" (Schroeder, s. 18). 
işlemlerin basm önünde veya iştirakiyle yapmlmasma, kişilerin basmla seruhu cevapl görüģtürülmelerine, görüntülerinin a!ınmasma. cşhir edilmelerine sebebiyet verilmez ve soruşturma evrakı hiçitir sekilie vayımlanamaz." "Kolluk kuvveti faaliyetlerjnin kamuoyuni duyurulmass amacıyla, yakalanan kişilerin kimliklerini ilıtiva elmeyen olay bilgileri, basm bildirisi şeklinde ve yetkilj birimler latrafindan kolluk kuvvetlerinin basına bilgi vermelerine ilişkin izel mevzual hïkümleri dikkate almarak basm-yayın organlarma bildirilebilir:" Dileri\%, son derece yerinde hükümler ihtiva ealen bu yönemelik, sadece kağıt üzerjnde kalmaz ve etkililiği sağlanabilir.

Tuluklama koruma tedbiri de toplumumuzda peșin bir ce/at barak alğdanmakta ve ne yazık ki pek çok olayda bu sekikle usgulanmaktaklır. Yukarıda değindiğimiz üzere tutuklanan silnık kann "ceraevine gönderildigi", bassn tarafindan ilan edilmekte, toplumun ilgilendigri davalarda verilen tahliye kararlarmm ise, kimi taman. "yönlendirilmis (manipule edilmiş) beraetler" alarak sumuldugu gịrülmekıedir. Samıkların tutuklı kaldıkları süreler de, baren makıl süreleri aşmakta ve adeta peşin ce\%alara dönüşmektedir".

\section{AVRUPA İNSAN HAKLARI SÖZLEŞMESI VE SUÇSUZLUK KARİNESI}

\section{AİHS MADDE $6 / 2$ VE "SUÇ ISNADI"NIN BULUNMASI ZORUNLULUĞU}

AİHS mal, 6/2 uyannca "Bir suç ile itham edilen her şahı suçlukuğu kinunen sabit oluncaya kadar masum silyılur."

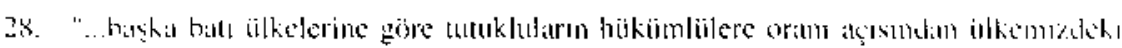

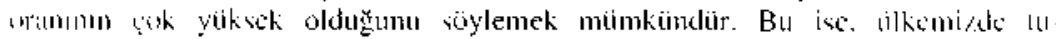

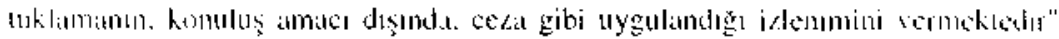
(Téaik. ᄂ. $4(0)$.

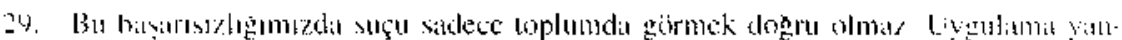

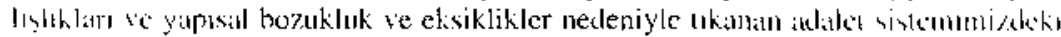

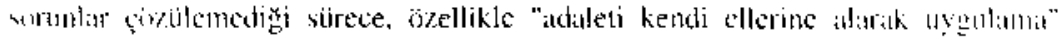

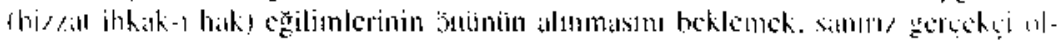
masciciatir. 
Görüildüğü ve yukarnda da değinildiği üzere. AİHS. "suçsuzluk" değil, "masumluk" terimini kullanmaktadır. Ancak hemen belirtelim. bu farklılığın, Sözleşmenin uygulanmasında esası etkileyen bir sonuç doğurduğunu sanmıyoruz.

AİHS md. 6/2'ye göre suçsuzluk karinesinin ileri süirülebilmesi, şahıs hakkında bir suç isnadının bulunmasına bağlıdır. Burada kastolunan suç, ceza hukuku anlamında suçtur ${ }^{\text {.4! }}$.

Suç isnadının bulunduğunu kabul için ceza davasının açılmış olması şart değgildir. Çünkü AIHS md. 6'mın amacı, genel bir ifádeyle, savunmanın hakların güvence altına almaktır". Bu amaç doğrultusunda, 6. maddenin sağladığı güvenceler, ceza davasının açılmasından önce başlamaktadır. Şöyle ki, devletin, kişinin bir slļ̧ işlediğg şüphesine dayanarak yaptrğı eylem ve işlemlerinin $s \ddot{z} z$ konusu kişiyi esash olarak etkilemesi durumunda, AIHS md. 6'nın uygulanmasi gereklidir.

AİHM'ne ve AlHK'na göre, devletin kişinin durumunu esaslı biçimde etkileyen ve bu itibarla, suç isnadi kabul edilmesi gereken eylem ve işlemleri, dava açılmasından başka, kişi hakkında müzekkere kesilmesi ile üstünün veya işyeri ya da mesken gibi sıkı bir şekilde ilgili olduğu yerlerin aranmasıdır. Polis tarafindan yürüttiilen ve tanıklarm dinlenmesi gibi doğrudan "hedef"teki kişiyi, yani şüpheliyi etkilemeyen eylem ve işlemler ise, suç isnadı olarak kabul edilmemiştir ${ }^{32}$.

\section{CEZA HUKUKU ANLAMINDAKİ SUÇLARIN NELER OLDUĞU SORUNU VE BU SUÇLAR İLE İDARİ SUÇLARI AYIRMANIN ÖLÇÜTLERİ}

AIHHS md. 6'nın uygulanabilmesi için suç isnadının, ceza hukuku anlamındaki suçlara ilişkin olması gereklidir. Ancak AIHM,

30. Gomien/Harris/Zwaak, s, 179.

31. Gomicn/Harris/Zwalk, s.179.

32. Gomien/Harris/Zwatk, ss. 179-180. 
"ce\%a hukuku anlamındaki suçlar"ın neler olduğunu belirlcrken. âkit devleticrin iç hukukuyla kendini tam anlamnla bağlı salymitmaktadır. Mahkemeye göre, bir âkit devlet, Sörleşmeye uyg̣n olmak kaydıyla dilediği fïli, ceza hukuku anlamnda saç olarak diizenleyebilir. Âkit devletlerin, kendi mevzuatlarmda idari suçla öngümmelcri cle münkündür. Ancak bir âkit devlet, bir fiili. AlHS'nin 6. marldesinde sağlanan güvenceleri bertaraf etmek amacıyla "idari suç" olarak dǜenlemişse, bu durum, Sözleşmenin ihlalidlir "i.

Hangi fiillerin ce'za hukuku anlammo suç teşkil etmesi ya da hanğ trillerin iđari suç olarak ve bu arada disiplin suçu olaralk clïzenlenmesi gerektiği konusunda evrensel ölçütler ve listeler. elhette yoklü. Buna karsm, Sözleşmenin özellikle 6. maddesindeki güivencelerin uygulanmasm âkit devletlerin kendi takdirlerine $\mathrm{b}_{1}-$ rakmak iskmeyen AJ̈HM, bu konuda çeşitli ölçütler gelişlimek /1)runda kialmossirit.

Kendi devletlerinin "askeri disiplin kurallăı" çerçevesind haklarmda "idari ceza" uygulanan Hollandalı askerlerin açiı Engel davassmdia ${ }^{i 5}$ verdiği kararda Mahkeme, isnadın ce\%a hukukuna aiı hir suça dair olup olmadığını hükme bağlarken. şu ïlçütlen tesbit etmiştir:

-Suçu düzenteyen hukuk kurallarının. âkit devletin ce\%a hukukuna m. disiplin hukukuna m, yoksa her ikisine birden mi ait olduğti.

-Sulçun niteliği.

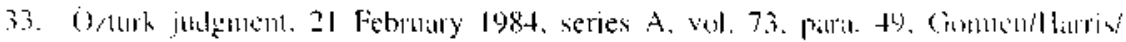

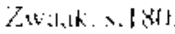

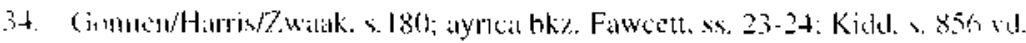

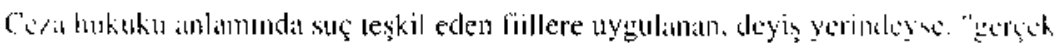

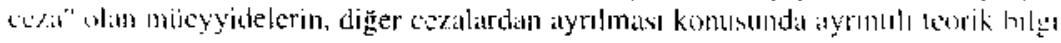
icin lok\%. Hatlzogulliar. Ceza Normu, s. $205 \mathrm{vd}$.

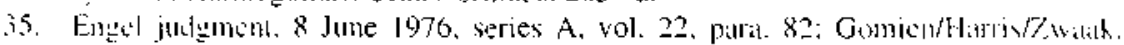
$\therefore .13+4$ 
-Ilgili kişinin, soruşturma sonunda maruz kalma riski altunda bulunduğgu cezanın ağırlık derecesi.

Disiplin müeyyideleri ile cezai müeyyidelerin birbirinden farkını ortaya koymak açısından, Weber davasında verilen karar da son derece önemlidir ${ }^{3 *}$. Weber davasında, davacı (AIIHM'ne başvuruda bulunan kişi) gazeteci, yürütülmekte olan bir ceza soruşturmasının gizliliği kurallarını bir basın toplantısı sırasında ihlal ettiği gerekçesiyle, duruşma yapılmadan, dosya üzerinden yürütïlen bir yargılama sonucunda, mahkum olmuştur. AİHM, söz konusu kararında, disiplin müeyyidelerinin ortak özelliğinin, belirli gruplara mensup üyelerin, kendilerine ilişkin davranış kurallannı ihlal etmeleri halinde uygulanan mieyyideler olması gerektiğini belirtmiştir.

Soruşturnanın gizliliğini ihlal eden davranışların idari suç olarak düzenlenmesi ve cezalandırılması ise mümkündür. Soruşturmanın gizliğine dair kuralların muhatabı, öncelikle hakimler, diğer hukukçular ve mahkemenin teşkilatında doğrudan görev alan kişilerdir. İ̧ hukukta disiplin kuralı olarak öngörtilmüş bir kural. eğer soruşturmayla ya da mahkemeyle ilgili kişi gruplarının d1şındaki çok geniş bir kesime, daha doğru bir ifadeyle, ayrım yapmaksızın herkese hitap ediyorsa, artık gerçek anlamda bir disiplin kuralı değildir ve içerdiği müeyyide de, disiplin müeyyidesi olarak nitelendirilemez. Nitekim somut olayda, söz. konusu "disiplin kuralı" herkesi muhatap aldığına göre, esasen bir disiplin kuralı olarak kabul edilemez.

Her ne kadar AIHM'ne göre bir davanın tarafları, mahkemenin yargl yetkisinin üzerlerinde kullanıldığı kişiler olmaları nedeniyle. ¿lisiplin hukukuna değil, ceza hukukuna tabi olsalar da ${ }^{i}$, bu esasen, muhakeme faaliyeti dışındaki hareketleri açısından disiplin hukukuyla bağlı olmadıklarını ifade eder. Muhakeme faaliyeti s1-

36. Weber judgment, 22 May 1990, series A, vol. 177, para. 33; Gomien/Harris/2walak. s. 180 .

37. Weber judgment, 22 May 1990, series A, vol, 177. para. 33. 
rasinclaki hareketleri. ömeğin duruşına smassmda, duruşma sitfontunelaki uygunsu/ ve kural dişı davranşlarl nedeniyle, yerel mahkemenin haklarnda disiplin tedbir ve cezass uygulamas mümkündür. Sïzlesmenin 6. maddesindeki guvenceleri benaraf cmeh amaciyla yerel mahkemenin böyle bir yetkiyle donatıldigl akit dev. letin kötüniyetli olduğ ve dolayısıyla sözü geçen madóenin. bu hallerde de uygulanması gerektiği kabul edileme\%. Nitekim AlHM. Ravnsborg davasında verdiği kararında ${ }^{i x}$, yerel mahkemenin muhakeme sirasinda meydana gelen uygunsuz ve kural diş daxranışan cezalandırma yetkissinin, onun gereken düzen içcrisinde yarglanı yapmak görev ve yetkisinin ayrılmaz bir parçąsı olcluğuna hükmetmiştir. Mahkemeye göre bu yetki, ceza hukuku anlammıla bir suçun cezalandırılmasına ilişkin de ğildir; bir disiplin vetkisidir.

AlHM ve AIHK nun, yukanda açıklamaya çălştı. stlę w es/a hukuku anlamında suçlar birbirinden aymmakla kul-

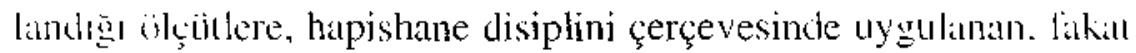

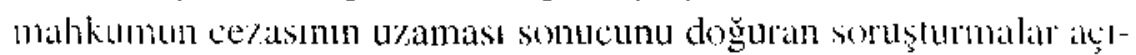
smolim da bassivurduğu belirtihnelidir".

\section{SUÇSUZLUK KARINESININ CEZA MUHAKEMESINDE ETKILILLIĞININ SAĞLANMASININ ÖLÇÜTLERI}

AİHM, suçsuzluk karinesinin etkililiğginin sağlammasmun đ̈jçutitlerini hükme bağladığı Barberà, Messeguè ve Jabardı datvassundaki kitratronda ${ }^{+1)}$. şu hususlara yer vermiştir:

- Yerel yarglama makannmn hakimleri, muhakemeye. samtğ isnad konusu suçu işlediği önyarğıs ile başlamannalıdır.

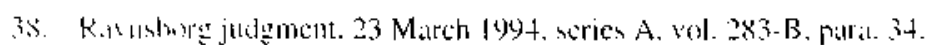

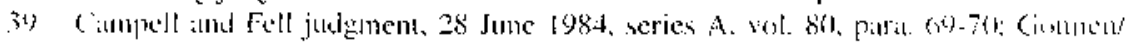
Itirriv/wathes. 180 .

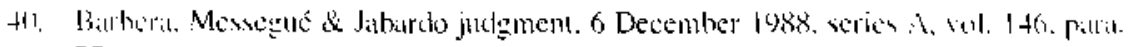
$7 ?$ 
-Muhakemede ispat yiikü, sanıkta değil. savcida olmalıdır. Savel, sanı̆̆ mahkum ettirmeye yetecek delil araçlarını makhkemeye summa yükü altındadır.

-Saveı, açacağı davadan sanı̆̆ haberdar etmelidir. Böylece sanığa, savunmasın hazırlama ve sunma imkan tamınmalıdır.

-Şüpheden. sanık yararlanmalıdır.

AlHM, Barberà, Messeguè ve Jabardo davasında, suçsuzluk karinesinin ihlal edildiği sonucuna ulaşlabilmesi için, İspanyol yerel yargılama makamının, hükümden önce sanığı suçlu olarak kabul ettiğini gösteren bir kararının olması gerektiğini ifade etmiştir. Yerel yargılama makamının vermiş olđuğu kararların bu nitelikte olmanası nedeniyle Mahkeme, Sözleşmenin 6/2. maddesinin ihlal edilmediği sonucuna ulaşmıştır.

\section{AIIHS MADDE 6/2'NİN BÜTÜN RESMİ MAKAMLARI BAĞLAMASI}

Mahkeme ve Komisyona göre, AIHS nin 6/2. maddesi, sadece yargılama makamlannı değil, devletin bütün resmi makamlarm! baglar. Allenet de Ribenot davasmda ${ }^{41}$, davaci, tutuklanmasindan sonra ve hakkında ceza davasının açılmasından önce, İçişleri Bakanmm ve soruşturmadan sorumlu polis yetkilisinin düzenlediği bir basm toplantısında, kendisini suçlu olarak kamuya duyurmalarının. suçsuzluk karinesinin ihlali olduğunu ileri sürmüştür. AlHM bu davayı haklı bularak, kabul etmiştir.

AlHK da Ísviçre'ye karşı yapılan bir başvuruda ${ }^{4}$. suçsuzluk karinesinin, herşeyden önce, sanığa, her türlü ceza muhakemesinde sağlanan bir güvence oldugunu belirtmiş, ancak kapsamınm bundan daha geniş olduğunu ifade etmiştir. Komisyona göre, AİHS md. 6/ 2"deki suçsuzluk karinesi, kamu görevlilerinin kişilere, yetkili bir

41. Allenet de Ribenot judgment, I0 February 1995, series A. vol. 308, parrit. $31-37$.

42. Krialse v. Swiczerland. no. $7986 / 77$. decision of 3 Octuber 1978, d.r. 13. s. 73, 7576 
malhkeme tarafindan suçlu bulunmalarından önce, suçlu gibi davranmalarıı engelleyen bir jlkedir. Bu itibarla, kamu görevlilerinin. bir kişyi. ycckili mahkemece suçlu oldığuna henǜ katrar rerilmedig̣i bir aşamada, suçlu olarak kamuya ilan etmeleri, ilkenin ihlali anlamma gelecektir.

Komisyon, yukarıda açklanan karannda, kamu gürevlilerinin ısplumu bilģlendirmelerine de değinmiştir. Buna göre, kamu gijrevlilerio, hir şüphelinin yakalandığını, tutuklandığını, hatta suçunu ikrar eltiğini bildiren açıklamalan, suçsuzluk karinesini ihlal eme\%. Suçsuzluk karinesini ihlal edecek olan, bu resmi açıklamalarda. sii konusu kişinjn suçlu olduğunun duyurulması olacaktır.

\section{DAVANIN ESASINA GİRILMEDİĠI DURUMLARDA AİHS MADDE 6/2'NIN UYGULANMA OLANAĞI}

Suçsurluk karinesi ile ilgili çok önemli bir dava da Minelli davasıdit': AİHM'nin. Sözleşmenin 6/2. maddesinin ihlal edildiğgine karar verdiği bu davada yerel mahkeme, işin esasma grimediğ ve bu nedenle sămı̆ (daha sonra. AtHM önünde davac1). savunma hakkım kullandırmaksızın suçlu bulmadı̆̆ bir ceza davasında, muhakeme masraflarından bazılatını ödemeğe ve karşı tarafın yapoğ takip masrafların tazmin etrneğe mahkum etmiştir. Yerel mahkemenin davann esasma girmemesinin sebebi, davanm /almanaşımına uğramış olmasıdıl:.

AİHM bu olayda vermiş olduğu kararmda, 6/2. maddenin. cesa davasının tamamında uygulanması gerektiğini vurgulamışır. Bu iıibarla, davanın sonunda verilen karann ya da işin esasma girilip gitilmemesinin. suçsuzluk karinesinin daha önceki bir aşamada ihlat edłlmesini haklı kılmayacağını ifade ederek, âkiı devleti mahkum etmiştiritit.

4.3. Minclli fudgment. 25 March 1983, scries A, vol, 62. paral. 30-37.

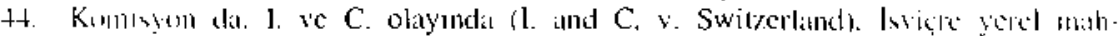

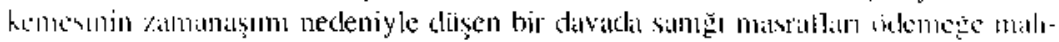

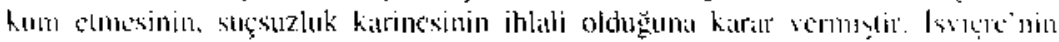

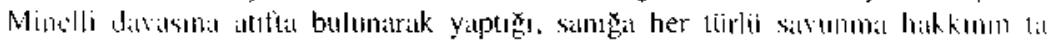


Şimdi de, Nölkenbockhoff davasını ve Mahkeme ile Komisyonun, 6/2. maddenin ihlal edilip edilmediği hususunda dïştükleri görüş ayrılığını incelemek istiyoruz.

Nölkenbockhoff davasında, davacının kocası, bir cera davasinda mahkum olduktan. ama bu mahkumiyet hükmünü tenyiz. ettikten sonra vefat etmiştir. Davacı, yerel mahkemeden, eşinin ceza davasında yapmış olduğu masrafların tazmin edilmesini istemiştir. Yerel mahkeme, temyiz sonunda mahkumiyet hükmünün onanmasının kuvvetle muhtemel olduğu gerekçesiyle tazminat talebini geri çevirmiştir.45.

Komisyon, başvuru sahibinin talebini, suçsuzluk karinesinin. temyiz dahil, ceza muhakemesinin her sathasinda uygulanmasi gerektiğini ifade ederek, haklı bulmuştur ${ }^{\text {th }}$. Buna karşın Mahkeme, davayı reddetmiştir. Red gerekçesi, Sözleşmenin ve esas itibariyle 6/ 2. maddesinin, âkit devletleri, muhakemenin herhangi bir nedenle kesin hükümden önce sona ermesi durumunda, sanığın zaranın karşlamakla mutlak olarak yükümlï kılmadı ğıdır ${ }^{\text {? }}$.

\section{SUÇSUZLUK KARİNESÍNIIN SAVUNMA HAKKIYLA ILIŞKISI}

Yukarıda incelediğimiz Minelli karanının asıl önemli ve ayırıcı yönü. sanığın suçlu olduğu önyargısını ortaya koyan ve ona savunma hakkı tanımmaksızın verilen bir mahkeme kararının, suçsuzluk karinesini ihlal edeceğinin AlHM tarafından ifade edilmiş olmasid $11^{4 k}$.

nındığ yolundaki savunmasını ise. Sözleşmenin 6/2. maddesi hijkmünuin. 6. malddedeki haklardan ayrı ve bağımsız olduğu, bu itibarla, savunma hakkına saygı gösıcrilmesinin, suçsuzluk karinesinin ihlaline engel olmaya yelmeyece ğ gerekçesiyle reddetmiştir (Gomien/Harris/Zwatak, ss.185-186).

45. Nörkenbockhotf judginent, 25 August 1987, series A, vol. 14], para. 11-22.

46. Niblkenbockoff case, opinion of the Commission. parat 44-58. annex to the Nobkenbockhoff judgment of 25 August 1987, series A. vol. 141.

47. Nökenbockholf judgment. 25 August 1987, series A. vol. 141, para. 35-40.

48. Gomien/Harris/Zwalak, s.183. 
AIHHS mul. 6, dürüst muhakeme hakkın dì /enlemekledir. Dürüist muhakemenin temeli, yukarıda da belirttiğmiz üzcre. santklara kendilerini savunma hakkınn tanmnnasi ve bu hakka, diarüsiçe sayg duyulmaskdur. Maddenin 1. fikrası, genel olarak diurtist muhakemeyi. 3. fikrasi ise, tahdidi olmamak kaydlyla. dieüisi muhakemenin hayata geçirilmesinde sayg duyulmas \%orunlu olan asgari haklan hïkme bağlamaktadır". Suçsurluk karinesi, bu ikj fikfamm arasında, clürüst muhakemenin bir parçass ve helki de izzi olarak diizenlenmiştir. Isnad konusu stçun gerçekten o sims laratından işlenip işlenmediğini ortaya çıkarmak için mulakeme yaprimasmun nedeni, muhakemenin başlangucundi, sànğgn suçsuy kabul calimesidir. Böylece çelişme yöntemiyle sentcre ulisşlmats miimkiins olikaktır.

Sanığa savunma hakkı verilmiş olsa dahi, mahkumiyel kitratondan änce sanığın suçlu clarak kabulü, elbette suçsurtuluk kiłrinesinin ilhlali anlamına gelecektir. Minelli kararndala vurgoulanmak istenen, suçsuzluk karinesinin içeriğjnde sirvunma hakkının da yer aldığgdır. Bu itibarla, sanı ğ peşinen suçlu kabul eden bir yartylama makam karar, savunma hakkmo da illat edeceklir.. Sarunma hakkının suçsuzluk karinesi bağlammela inemi.

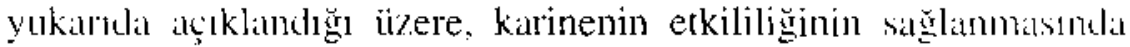
uyuhnası gereken ölçüłlerin sunandığl Barberà. Messeguè ve Jabardo davassondia da dile getirilmiştir.

\section{BERAET KARARINDAN SONRA HÜKMEDILLEN MAHKEME KARARLARINDA SANIĞIN SUÇIU OLDUĞU ŞÜPHESINNE YER VERİLMESI}

AİHM"nin içtihadına göre, bir ceza muhakemesi sırasında I11tuklanaın sanığın, beraet ettikten sonra talep ettiği tazminaıın reddedilmiş olması, suçsuzluk karinesinin ihlahi sayılma\%. Ancath bunun için yerel mahkemenio, tazminat talebini reddoderken. sil-

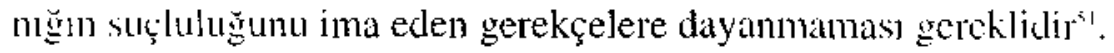

4). Schricaler. sh, 6.25.

5i1. Bki. Yukaldald di. + .

51. Gumicn/Hatris/Lwalik, ss. 184-185; alynca bkz. Yolmes, s. 127. 
Englert davasında, davacı (yerel mahkeme önïndeki sank), Alman yerel mahkemesinde şiddet sebepli görevi ihmal suçundan mahkum olduğu halde, ırza geçmekten beraet etmiştir. Bunun üzerine davacı, yargılamada tutuklu kaldığı süreler için devletten táminat talebinde bulunmuştur. Bu tazminat talebi, Alman yerel mahkemesi taratundan reddedilmiştir. Red gerekçesi, samığn tucuklanması anında, suçsuzluk karinesini çürüten çok sayıdà sebebin bulunması ve mahkumiyetin, beraete kiyasla daha muhtemel

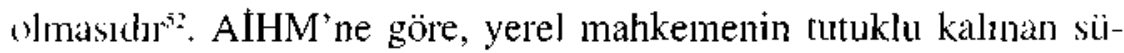
reyle ilgili tazminat talebini reddetmesi, beraet etmiş sanığn üzerinde halen mevcut bir suçluJuk şüphesine işaret etmemektedir. Bu itibarla Mahkeme, suçsuzluk karinesinin ihlal edilmediğine karar vermiştir ${ }^{\text {is }}$.

Davacmn, tutukluluk nedeniyle tazminat talebinin yerel mahkemece geri çevrildiği Sekanina davasında ise AlHM, Sözleşmenin 6/2. maddesinin ihlal edildiǧine hükmetmiştir.

Sekanina davasında davac1, Avusturya yerel mahkemesinde, adam öldürmnek suçundan beraet etmiştir. Bunun üzerine davacı. tutıklu kaldığı süreler için tazıninat talebinde bulunmuştur. Avısturya mevzuatına göre beraet eden sanığa tazminat ödenmesi, suçun onun tarafindan işlendiği şüphesinin tamamen yenilmesine bağlıdır. Nitekim tazminat talebini reddeden yerel mahkeme, bu karrarma gerekçe olarak, suçun sanık tarafindan işlenip işlenmediğine dair şüphenin tamamen giderilmesinin mümkün olmadığı hususunu göstermiştir. Temyiz mahkemesi, red karanını onamıştır ${ }^{\text {के }}$.

AlHM'nin, Sekanina davasında Avusturya'yı mahkum ederken göstermiş olduğu gerekçe, son derece önemlidir. Mahkemeye göre. ceza muhakemesinin, işin esastna girilmeksizin sona erdirildiği durumlarda, şüphenin dile getirilmesi mümkündür. Ancak kesin hükümle beraet karan verildikten sonra, artık sanığın şüphe altında ol-

52. Englert judgment.25 August 1987. series A, vol 123, parat. J1-18.

53. Englert judgment.25 August 1987, series A. vol J23. parat 34-41

54. Sekanina judgment, 25August 1993, series A, vol. 266-A. pala 6-13. 
duğ̆ gerekçe gösterilerek uyuşrnazlıkla ilgisi olan bir diğer işlem yapılamar. Bu itibarla, beraet karan verildikten sonra talep edlilen bir tałminatın, sanık üzerindeki şüphenin devam ettiği gerekçesiyle reddi, suçsuzluk karinesini ihlal etmiştir"s.

\section{SUÇSUZLUK KARİNESI VE TUTUKLULUKTA MAKUL SÜRE}

AlHS md. $5 / 3$ uyarmea "Işbu maddenin $1 / \mathrm{c}$ fikrasındal derpiş edilen şartlatra göre yakalanan veya tevkif edilen herkesin. hemen bir hakim veya adlî görev yapmya kanunen mezun kılınmış dlğ bir memur huzuruna çıkarılması lâzım ve mâkul bir süre içerisinde muhakeme edilmeye yahut adli takibat sirusinda serbest bırakılmaya hakkı vardır. Salıverme ilgilinin duruşmada hatıı bulunınasını sağlıyacak bir teminata bağlanabilir."

Sơz üi geçen 5/3. maddedeki "makul süre". tutukluluklaı geçirilecek makul süredir. Muhakemenin makul sürede sonuçlanması gereğ ise, Sözleşmenin 6. maddesinde hükme bağlanmıştır. Bułla gëre, bir dava, haklı sebepler varsa, uzun süre devam etmiş olabilir. Bïyle hir durumda, 6. madde ihlal edilmemiştir. Oysa ayn davada sanık, makul süreyi aşar şekilde tutuklu kalmışsi, 5/3. maude ihlał edimiş olacakıı"s".

55. Schimimat fudgment. 25 August 1993, series A. vol. 266-A, paral. 23-31.

"Astupa lnsin Hakları Komisyonunun ve Mahkemesinin kitrarlarma geils, herilith

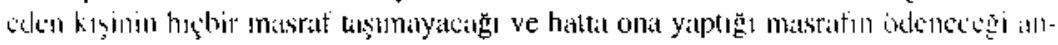

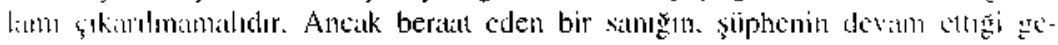

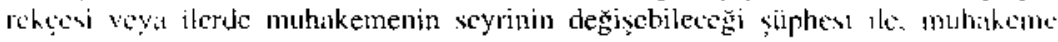

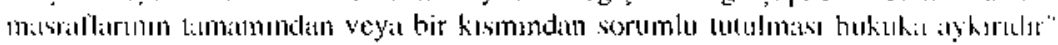
(Sibrocoder. 1.25$)$.

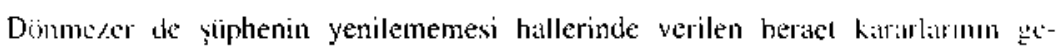

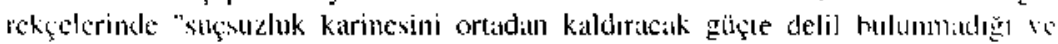

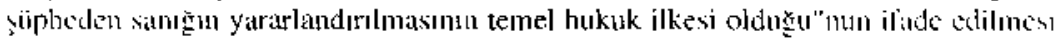

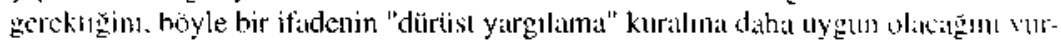

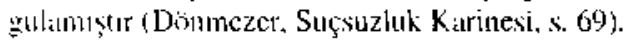

56. Gïlciiklii/Gizzibiiyük, s. 226; Gomien/Harris/Zwiak, s. 149; AllM. Stïgmiollo .14t:ancust. 10.11.1969. series A. vol. 9.s. 40. 
AlHM'nin içtihatlanna göre, makul süreyi aşan tutukluluk halleri, Sözleşmenin 5/3. maddesinin yanında, suçsuzluk karinesini düzenleyen 6/2. maddesinin de ihlali sonucunu doğurur ${ }^{5}$. Mahkeme, Neumeister davasında verdiği kararında ${ }^{\$ 4}$, makul süreyi aşan tutukluluk hallerinin, suçsuzluk karinesini ihlal ettiğini hükme bağlamıştur. Burada, suçsuzluk karinesi ile tutuklulukta makul sürenin ilişkilendirilmesinin altında yatan gerekçe, makul sürenin üzerindeki tutukluluk hallerinin, kesin hükümle mahkumiyetten önce uygulanan bir peşin cezaya dönüşmesi olsa gerektir.

Tutuklulukta makul sürenin aşılıp aşılmadığı husısunun, her somut olayın şartlarına göre teshit edildiği belirtilmelidir ${ }^{5}$. Mahkemenin ve Komisyonun yerleşmiş içtihatlannda, makul sürenin tesbitinde şu hususların dikkate alınması gerektiğine hüikmedilmişsir ${ }^{(x)}$ :

-Hürriyetin kısıtlandığı sürenin ne kadar olduğu,

-Isnad konusu suçun niteliği ve mahkumiyet halinde verilmesi mubtemel cezanm ne olduğu,

-Hürriyet kısıtlamasının, sanık üzerindeki maddi, manevi ve diğer etkilerinin neler olduğu.

-Sanığn davramışları.

-Soruşturmanın yürütülme şekli ve üslubu,

-İlgili adli makamların işlemlerinin neler olduğu.

\section{SUÇSUZLUK KARINESI VE FİLI YA DA HUKUKİ SORUMLULUK KARİNELERİ}

AİHM, pek çok kararında, bazı hallerde kanunun fiili ya da hukuki sorumluluk karinesi getirebileceğine hükmetmiştir. Burada

57. Gölciiklü/Gözúibijyiik, s. 224.

58. Neumeister judgment, 27 June 1968, series A, vol. 8. s. 31, parit. 4: ayrica bkz. Go. mien/Hartis/Zwalak. s. 148.

59. Gomien/Harris/Zwałk, s. 149; Gölcüklï/Göziibuiyük, ss. 223-225; Çàvuşoğlu, s. 34

60. Gomien/Harris/Zwalak, s. 149. 
Mahkemenin benimsediği ölçüt. makul stnırlar içinde kahnmlası ve samlŭın savunma hakkımm ihlal edilmemesidiri!n.

Örneğin Salabiaku kararında Mahkeme, fiili veya kanunni karinelerin her hukuk sisteminde bulunduğunu ifade ettikten sonra. cera hukukundaki karinelerin, Avrupa Insan Haklan Sörleşmesi açısından belirli sumılar dahilinde kabul edilebileceğini v'urgulamışur. Mahkemeye göre tïili veya kanuni karinelerin bulunduğ hallerde, sanı ğa bunu çürütme imkanı mutlaka tanımmalı. bir digger iladeyle, böyle bir karinenin kabulü. savunma hakkm kisitlamanalidur. Aynca karinenin Sözleşme açsından kabul colilebilirigi. ceza davasinda risk altuna sokulan menfiatle de dogrudan ilgilidior".

\section{SONUÇ}

Suç:surluk karinesi, Fransız, thtilali ile birlikte tüm Kı1a Alrupasina yayllmş ve bugün, bütüin medeni devletlerin ortak bir dcğeri haline gelmiştir.

Anayasamı/ın 38/4. madkesine göre suçsuzluk karinesi. kişilerin temel bir hakkıdır. Yine Anayasamızın 15/4. madkesinde. savaş, scterberlik, sıkıyönetim veya olağanüstü hăllerde dahi suç-

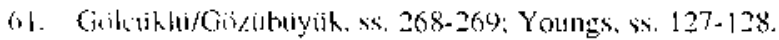

6. S. Siblabiatid judement. 7 October 1968. series A. vol. 1+1. parat. 28-24.

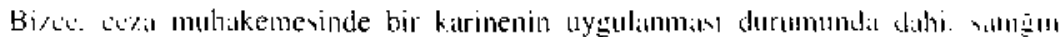

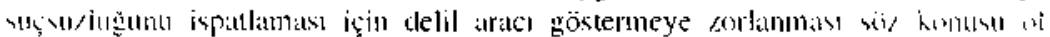

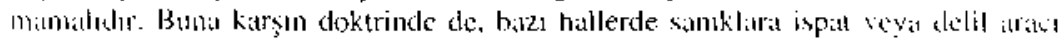

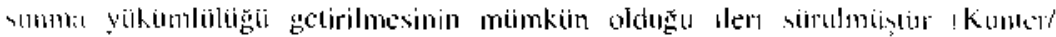

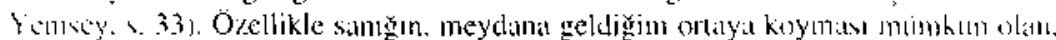

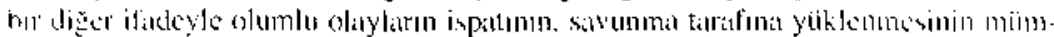

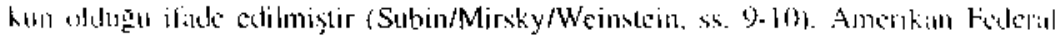

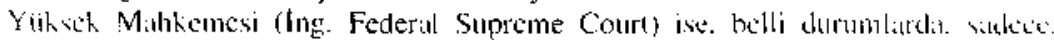

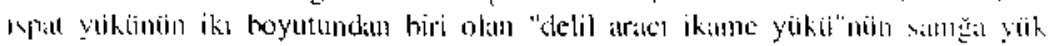

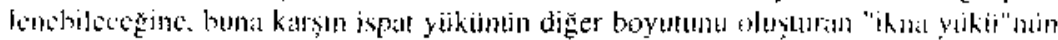

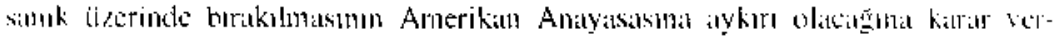
mişlï isupreme Court of the United States. Francis v. Framklin. 1985. McCornich/ Sullim/Wellhom 1ll, sis. 889-901). 
luluğu mahkeme kararı ile saptanıncaya kadar kimsenin suçlı sàyılamayacağı hükme bağlanmıştır.

Suçsuzluk karinesi, sadece Anayasa değil, Türkiye tarafından onaylanarak bir iç hukuk normu haline gelmiş olan AIHS md. 6/2 tarafindan da güvence altına alınmıştır.

Bazı hukuki metinlerde, suçsuzluk karinesi yerine "masumluk karinesi" denilmektedir. Ancak ceza muhakemesinde, kişinin santk sıfatım almasıyla birlikte, sanıklık statüsüne girmeyenlere uygulanamayan ve tutuklama gibi kişi hürriyetini ciddi şekilde sinurlayan bazı koruma tedbirleri belirli şartlar altunda uygulanabiliu hàle geldiğine göre. Anayasanın 38/4. maddesinde "suçsuzluk" ibaresinin kullanılmış olmasını isabetli buluyoruz.

Buna karşın karinenin tanımı, gerçeğe uygun ya da sabit kabul edilen bir olaydan, başka bir olayın varlığı sonucuna gidilmesi olduğuna göre, "suçsuzluk karinesi" aslında bir karine değildir; kişinin suçlu olarak nitelendirilebilmesi ve hakkında cera hukukunun alanına giren müeyyidelerin uygulanabilmesi için, onun kesin hüikümle mahkum olması şartını getiren ve bu şart gerçekleşene kadar kişiyi suçsuz sayan bir varsayıma dayanan temel bir haktır. Fakat suçsuzluk varsayımının, karine olarak adlandırılması artık yerleşmiş bir tanımlama olduğu için biz de bu terimi kullanmayı tercih etik.

Sanık, kanunen suçsuz kabul edilen bir kişi olduğana göre. stıçu işlediğine dair akla ve mantığa uygun gerekçelere dayanan her tiirlü şijphe bertaraf edilmediği takdirde mahkum edilemeyecektir. Bu itibarla, şüpheden samığın yararlanacağını öngören ilkenin, sưçsuzluk karinesinin bir sonucu olduğunu söylemek yanlış olmayacaktır.

Kişilerin suçsuzluk karinesinden yararlanmasının bir diğer sonucu da, savunma hakkıdır. Sanık suçsuz kabul edildiği içindir ki ona savunma hakkı tanınmış ve bu hak muhakemede temel öneme sahip bir hak olarak düzenlenmiştir. 
Anayasimntzın düzenlediğg şekliyle suçsuzluk karinesinin. AlHS nden farkl olarak, herhangi bir suç isnadı olmayan hallertie. resmi makamlarea kişilere suçlu muamelesi yapılmasmı da yasakladığ belirtilmelidir.

Hukukun toplumsal bir kültür olmasına ve buna bağlı olaliak gencllikle toplumsal gelişmeleri takip etmesine rağmen, üilkemizde. sanı ğı suçsuz, olduğunu kabul eden hukuki düzenlemeler, iizuilerek belirtmek gerekirse çoğu zaman toplumumuzda yaygum olarak kabul gören "sanığın suçlu oldugu" anlayışından daha ileridir. Böyle olunca, mankemede değilse bile toplum ncrdinde aklanabilmek jçin samklar, çok kez, suçsuzluklarını ispat emek \%orundat burakilmakladir.

Şindi de AlHS bağlamında suçsuzluk karinesi ile ilģili açıklamalarnmızn ba\%ı esash noktalannı ve Sözleşme denetim organlarmn bu konuda geliştirdiği içtihatlardaki ilkeleti lopluka (ortaya koymak istiyoruz.

AlHS md. 6/2 uyarınca kişinin suçsuzluk karinesini ileri sïirebilmesi için, hakkında ceza hukuku anlamında bir suç isnadının bulunması gereklidir. AlHM'nin içtihatlars uyarnnca âkit devletler. Sizleşmeye uygun olmak kaydıyla, diledikleri fïileri ce\%a hukuku anlammola suç, diledikleri fïlleri ise idari suç olarak dijzenleyehilirler. Ancak âkit devletlerin AlHS md. 6udaki giivenceleri bertaraf etmek için bir fiili, idari suç olarak diuzenlemeleri. Sözleşmeyi ihlal eder.

AlHM ne göre bir isnadin ceza hukukuna ait bir isnatd olup olmadığgn tesbitte, fïli suç olarak tammlayan hukuk kuralının âkil devletin cera hukukuna ait olup olmadığı, suçun niteliğgi ve risk alunda bulunulan cezanın ağrlık derecesi önemlidir.

Yerel yalglama makamnnn hakimlerinin, muhakemeye sitnığın suļ işlediği önyargısı ile başlamaları: muhakemede ispat yiiküiıün save! yerine sanık üzerinde bulunmas1; savonnn, samığ dit- 
vadan haberdar etmemesi; sanığa savunmasın hazırlama ve sunma imkanının tanınmaması ve șüpheden sanığın yararlanmaması durumlarında AIHM, suçsuzluk karinesine saygı duyulmadığına hükmetmektedir.

Özellikle Sekanina davası ile Nölkenbockhoff davasında verilen kararlar karşılaştırıldı ğında, AtHM'nin, yerel adli makamların suçsuzluk karinesini ihlaliyle ilgili şu ölçüyü geliştirdiği anlaşılmaktadır: Yerel adli makamlar, beraet kararına rağmen sanı̆̆ın suçluluğu şüphesini dile getirmişlerse, suçsuzluk karinesi thlal ediłmiştir. Böyle bir şüphenin dile getirilmesi, genellikle, soruşturma sirasında tutuklu kalınan sürelerin tazmini için yerel adli makamlar nezdinde açılan tazminat davalarında söz konusu olmakıadır.

Eğer ceza davası beraetle sonuçlandıysa, tutuklama işlemi ne¿leniyle yapılan tazminat talebinin suçluluk şüphesine dayanılarak reddedilmesi, Sözleşmenin ihlalidir. Buna karşın, ceza davası beraefle veya mahkumiyetle sonuçlanmayıp, diğer herhangi bir nedenle sona ermişse, tazıninat talebi reddedilirken santğın suçlu olma ihtimalinin yüksek bulunduğunun gerekçe gösterilmesi. suçsuzluk karinesini ihlal etmeyecektir.

Mahkemenin geliştirdiği bu ölçüt, sanığın tutuklanınış olmasının. onun suçluluğuna bir karine teşkil etmediği esasma dayanmaktadır. Öyleyse sonuçta beraet etmiş bir sanığın muhakeme sürrecinde tutuklu kalmış olması, suçsuzluk karinesinin ihlali için yeterli değildir. Dolayısıyla, ceza muhakemesinin, davanın esasını çözen bir karardan önce, örneğin şikayetin geri alınması ya da zamanaşımı nedeniyle sona ermesi durumunda, tutuklu kalınan süre için yaplan tazminat talebinin, sanığın tutuklandığı anda suçlu olması ihtimalinin, suçsuzluğuna kıyasla daha fazla bulunduğg gerekçesiyle reddi, kural olarak suçsuzluk karinesini ihlal etmez.

Buna karşın, ceza muhakemesinin sona ermesinden önce saniğa kendini savunma imkanının tanınmamış olması, ceza muhakemesi, davanın esasını çözmeyen bir kararla sona ermiş olsa dahi. suçsuzluk karinesiyle bağdaşmayacaktır. Nitekim Minelli da- 
Vasinun davacısı, ramanaşım nedeniyle sona eren ceza davasunda. kendini savınma imkanı tanınmaksızın davanın düşmesine killa verilmesine răgnen, muhakene masraflarm: ödemeğe nulıkum elilmiştir. AİHM’nin söz konusu davada, suçsuzluk kirrinesinin ihlal edlildiğine karar vermesinin temel nedeni. bu alsa gerektir.

Mallkemenin ve Komisyonun içtihatları uyarmoa. ce\%a mu-

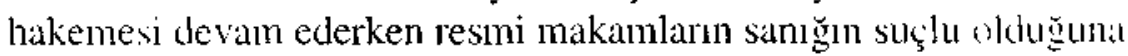
Jair yaptıkları açıklamalar da suçsuzluk karinesinin ihlalidlir. Ayrıca idd geçen denetim organlarına göre, tutuklulukta geçen sütreniı maku! sınırları aşması halinde de suçsuzluk karinesinin ihlali sio\% konusu olikakitr.

\section{KAYNAKÇA*}

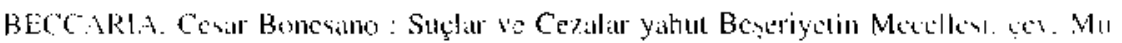
bilun Gisklii. lisimbul MCML.

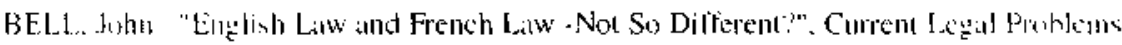

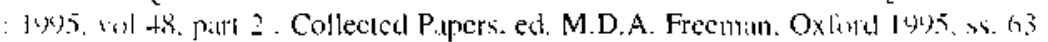
(6)

BLACK. Henry Campbell : Black"s Law Dictionary. USA 1979.

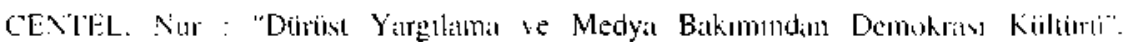

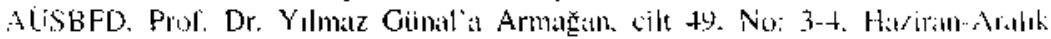
IM4. «. 57-72. (Dürüst Yargliama)

CENTEL. Nur :Cera Muhakemesi Hukukunda Tutuklaumat ve Yarkalamit. Istanhul fwy. (Tutuklama ve Yakalama)

ÇAVLŞOCı,U, Naz: Insan Hakları Avrupa Sözleşmesi ve Avrupa Topluluk Hukukuindiı Temel Hak ve Histiyether Üzerine. Ankatra 1994.

CROSS. Rupere : On Evidence. London 1974.

DANDO. Shagcments : Japancse Criminal Procedure çex. B.J. George Jr. LSA 146.

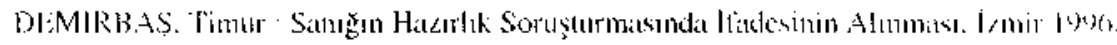

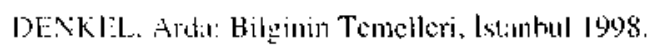

DERSIIOHITZ, Alan M. Reasonable Doubs: The Criminal Justes System amd the (). 1. Simpun Cilsi, New York 1997

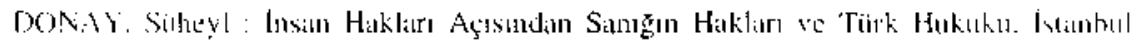
IU⿺廴2

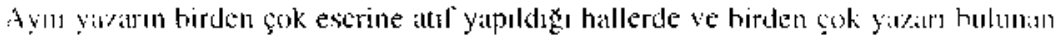

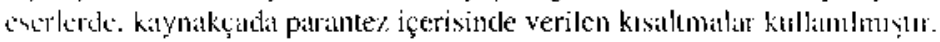


DÖNMEZER. Sulhi : "Surçsuzluk Karinesi Üzerine Dü şünceler". Prof. Dr. Nuruliah Kunter'e Armağan, Istanbuł 1998, ss, 67-74. (Suçsuzluk Karinesi)

DÖNMEZER. Sulhi : "Ceza Muhakemesi Kanumu 1999 Tasarsmmn Temel Jlkeleri". CMUK Scmpozyumu, Insan Hakları Avrupa Sözleşmesi ve Avrupa Inxim Hitklası Mahkemesi Kararları Karşısında 70. Yıldönümünde Ceza Muhakemeleri Usulii Kanumu. Marmara Üniversitesi Insan Hakları, Ceza Hukuku ve Kriminoloji Arastumat ve Uygulama Merkezi, Istanbul 1999, ss. 18-28. (Tasar)

FAWCETT. J.E.S. : "Criminal Procedure and the European Convention on Human Rights", Humitn Rights in Criminal Procedure, ed. J.A. Andrews. The Hague 1982. is. 17-30.

FEYZloĞLU, Metin : "Tanıklık ve Dürüst Muhakeme", Ankara 1998. (Dürüst Muhakeme)

FEYZlOGLU, Metin : "Húrriyeti Băglayı Cezalarda ve Tutuklama Koruma Tedbirinde Hïrriyetin Smılanmasinm Kapsamı, Sumrı ve Usulii Üzerine Bir Deneme". Yeni Tïrkiye, Yargı Reformı Özel Sayısı, Temmuz-Ağustos 1996, yıl 2, sayı I0, ss, 696-706. (Hürriyeti Bağlayıc Cezalarda ve Tutuklama Koruma Tedbirinde)

FEYZlOĞLU, Metin: Ceza Muhakemesi Hukukında Tanıklık, Ankara 1996. (Tanıkık)

FRANK, Jerome : "Facts Are Guesses". Crime, Law and Society, Readings Selected by Abrihalm S. Goldstein and Joseph Goldstein. New York 1971, ss. 12]-130.

GADAMER, Hans-Georg: Reason in the Age of Science, çev. Frederick G. Lawrence. Cambridge 1996.

GOLDSTEIN. Abratham S.: "The State and the Accused: Balance of Advanlage in Criminal Procedure". Crime, Law and Society, Readings Selected by Abriham S. Goldstein and Joseph Goldstein, New York 1971, ss. 173-2116.

GOMIEN, Donna, HARRIS, Divid, ZWAAK, Leo: Law and Practice of the Europein Convention on Human Rights and the European Social Charter. Germany 1996. (Gomien/Harris/Zwaak)

GÖLCÜKLÜ. Feyyaz. GÖZÜBüYÜK. Şeref : Avrupa Insan Hakları Sözleşmesi ve Uygulaması. Ankara 1996. (Gölcüklł/Gözübüyük)

HAFIZOĞULlARI, Zeki : Ceza Normu, Normatif Bir Yapı Olarak Ceza Hukuku Diizeni. Ankara 1996. (Ceza Normu)

HAFiZOGULLARI, Zeki : "Bir Kïltiir Ürimü Olarak Hukuk Düizenj", AüHFD, cilt 45. say1 1-4, 1996, ss. 3-2I. (Kültür)

HAFIZZOGULLARI, Zeki : Laiklik. Inanç, Düşïnce ve Ifade Hürriyeti, Ankară 1997. (Laiklik)

HOLTEN, Gary N., JONES, Melvin. E. : The System of Criminal Justice, Boston 1978. (Holten/Jones)

KAPANi, Münci : Katmu Hürriyetleri, Ankara 1981.

KEYMAN, Selithattin : Hukuka Giriş, Lefkoşa 1997. 
KIDD. C. I. F. "Disciplinary Proceedings and the Right to a Fatit Crimulat frial Linder the Faropain Convention on Humian Rights", International and Comparative l.ak

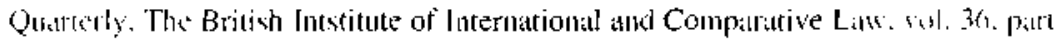
t. Oslative 1987, s. 856-872.

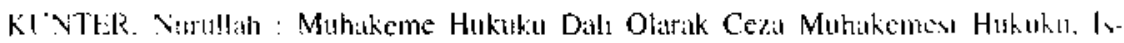
litnhul 198\%.

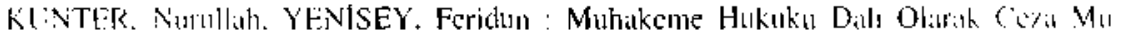
thakimui Hlukuku. Lstambul 1998. ( Kunter/Yenisey)

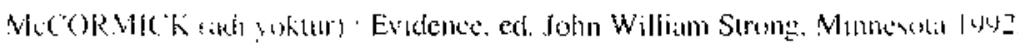

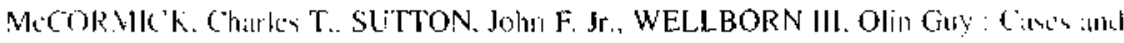

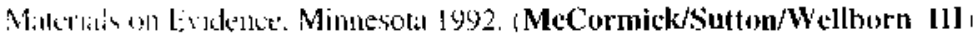

OZZGL〉, Fralp: CE/a Muhakemesmin Yenilennesi, Ankatra 1968.

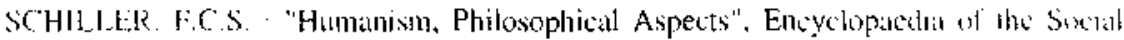

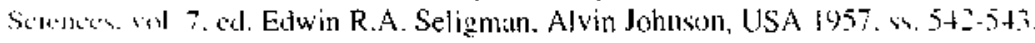

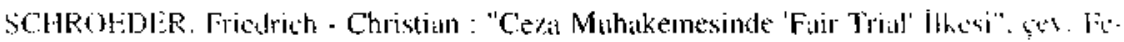
rislu!ı Yonisey. Durüst Yargolinma Hakkı, Lstanbul 1997, 4s. 1-57.

SHAPlRO. Binthatia I. : Beyond Reusonable Doubt and Probable Cinte. Histerical Perspritives in the Anglo-American liaw of Evidence, USA 199)

STLMP: Simllel Enoch : Socrates to Sartre, A History of Philosophy. Singapure loy.

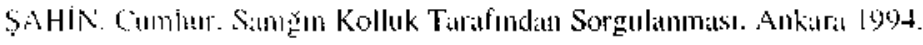

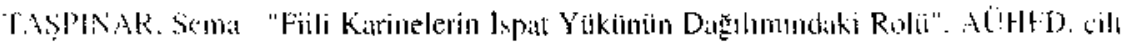
45. sily: 1-4. 1906, sis, 533-572.

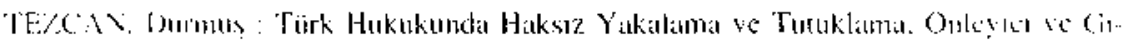
ileric Tothirler. Ankarit 1989.

TOROSI f: Mivitt Ce\%al Muhakemesi Hukuku. Altkara 1998.

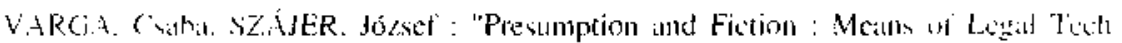

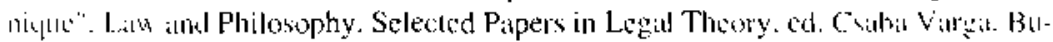

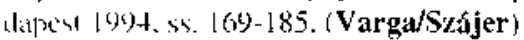

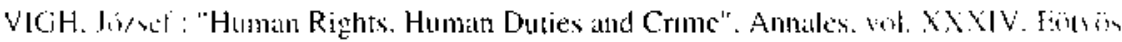
I.(1):and University, Budipest 1993. s5. 131-137.

WILLIAMS. Gianville: The Proot of Guilt. A Sudy of the English Crimumil Triall. Lin4. 1963.

YE:NISEY Furidun : Uygulanan ve Olmas Gereken Ceza Muhakemesi Huhuhu, Hit/rhih. Sintlyturmasi ve Polis. Astanbul 1993.

YOL'NGS. Raymond: English, French and German Compurative Latw. Grat Britian lym.

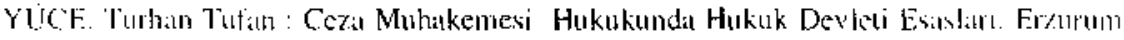
$196 \mathrm{~s}$ 


\section{KISALTMA CETVELI}

\begin{tabular}{|c|c|}
\hline AJHK (Komisyon) & : Avrupa Insan Hakları Komisyonu \\
\hline AlHM (Mathkeme) & : Avrupa Insan Hakları Mahkemesi \\
\hline AlHS (Sözleşme) & : Avrupa lnsian Hakları Sözleşmesi \\
\hline AÜHFD & : Ankara Üniversitesi Hukuk Fakiiltesi Dergisi \\
\hline AÜSBFD & : Ankara Üniversitesi Siyassal Bilgiler Fitkültesi Dergisi \\
\hline bkz. & : bakıniz \\
\hline BM & : Birleşmiş Milletler \\
\hline çev. & : çeviren \\
\hline CMUK & : Ceza Muhakemeleri Usulii Kantunu \\
\hline dn. & : dipnol \\
\hline ed. & : editör \\
\hline $\operatorname{lng}$. & : Ingilizec \\
\hline krş. & : karşılaștmom \\
\hline md. & : madde \\
\hline pariat. & : paragraff(lari \\
\hline s. & : sayfia \\
\hline ss. & : sayfalar \\
\hline USA & : United States of America \\
\hline$v d$. & : ve devalm \\
\hline vol. & : volume \\
\hline vis. & : ve saire \\
\hline
\end{tabular}

